\title{
Metode Pembelajaran Bahasa Arab Pada Program Khusus Perkuliahan Bahasa Arab STAIN Malang
}

\author{
A. Wahab Rosyadi
}

\begin{abstract}
Arabic intensive course at UIIS Malang makes use of the materials taken from 'Mulakhos al Arobiyah Linnasyi'in which offers the four-language skills in an integrated sequence. The nature of the materials requires the teacher to use direct method. This descriptive research is intended to find out the teaching techniques employed by the teachers in their teaching learning process. 75 out of 82 teachers and 200 student were involved as the research subjects. The findings revealed that the teachers used an elective method by paying more attention on creating a more conducive language environment.
\end{abstract}

\section{Latar belakang Masalah}

Bahasa Arab adalah warisan budaya yang tak temilai yang senantiasa menjadi simbul keagungan dan peradaban umat Islam .Bahasa yang dipilih oleh Allah SWT untuk menjadi bahasa Al Qur'an sebagai wahyuNya yang diturunkan pada nabi Muhammad SAW. Bahasa Arab sebagaimana bahasa asing lainnya pada dasarnya berfungsi sebagai: a). Alat untuk menyatakan ekspresi diri, b). Alat untuk berkomunikasi, c).Alat untuk mengadakan integrasi dan adaptasi sosial, d).Alat untuk mengadakan kontrol sosial. ${ }^{1}$

Ulul Albab, Vol. 3 No. 2, 2001 
Dewasa ini perkembangan pembelajaran Bahasa Arab di Indonesia menampakkan adanya kemajuan. Hal ini terbukti dengan banyaknya lembaga pendidikan di lingkungan Depag dan Diknas baik pendidikan formal maupun non formal yang didalamnya diajarkan Bahasa Arab.

STAIN Malang, memandang bahwa kemampuan berbahasa Arab merupakan syarat mutlak yang harus dipenuhi oleh setiap mahasiswa yang akan melakukan kajian Islam, seperti Tafsir, Hadist, Fiqih, Aqidah, Tasawuf dan lain sebagainya. Hal ini didasari eleh kenyataan empirik bahwa ilmu-ilmu tersebut ditulis sekaligus dijelaskan dengan menggunakan bahasa Arab. Secara rasional, sangat tidak memungkinkan seseorang menguasai disiplin ilmu-ilmu ke-Islaman seperti tersebut di atas, tampa memilik kemampuan yang utuh terhadap bahasa Arab.

Maka pada tahun 1997 dibukalah "program unggulan " untuk pembelajaran bahasa Arab secara intensif. Program ini dikelola oleh PKPBA (Program Khusus Perkuliaan Bahasa Arab).

Program ini dilakasanakan secara intensif selama 5 hari dalam seminggu mulai pukul 14.00 sampai 20.00 WB setiap harinya, dengan menggunakan materi ajar "Al Arobiyah Li al-Nasiin" (manhaj mutakaamili lighoiri Al naathiqina bi Al Arabiyah) dengan pendekatan All in one system/Al nadhariyah Al wihdah dengan ciri-ciri sebagai berikut:

- Melihat bahasa sebagai satu kesatuan yang utuh dan salimg melengkapi

- Memperhatikan empat kemahiran bahasa secara seimbang (Istima',Kalam, Qiroah, dan kitabah)

- Memperhatikan unsur-unsur bahasa (Aswat/bunyi huruf, Mufrodat/kosa kata, Qowaid/gramatika dan juga $\mathrm{Nabr} /$ stressing, maupun tanghim/intonasi. $^{2}$

- Dengan menggunakan metode langsung (Al thoriqoh Al Mubasyaroh) yaitu mengajar bahasa secara langsung tampa menggunakan bahasa ibu sebagai bahasa perantara. Disamping itu teknik pembelajarannya disesuaikan dengan langkah-langkah (al-Khutuwat al-Ta'limiyah) yang ada dalam petunjuk buku tersebut.

Dalam perkembangan berikutnya materi bahan ajar tersebut di atas,khususnya jilid 1,2,3 dan 4 dirangkum menjadi "Mulakhos Al Arobiyah linnasiin" dengan cara memilih dan memilah empat kemahiran berbahasa (Istima', Kalam, Kitabah, dan Qiro'ah) masing-masing dijadikan empat buku, dan meminimalisasi unsur-unsur 
bahasa, utamanya pada aswat (bunyi huruf), disamping itu penghilangan beberapa gambar yang merupakan media visual yang banyak membantu pemahaman materi bagi mahasiswa. Dengan perubahan bentuk materi tersebut di atas tentunta berdampak pula pada bentuk pendekatan (metode) yang digunakan dalam proses pembelajaranya.

\section{Perumusan Masalah}

Berdasarkan uraian pada latar belakang di atas, maka dapat dirumuskan masalah sebagai berikut:

a. Apakah jenis pendekatan (metode) yang digunakan dalam pembelajaran bahasa Arab dengan materi "Mulakhos Al Arobiyah linnasiin"?

b. Apa alasan penggunaan pendekatan (metode) tersebut ?

c. Faktor apakah yang sering diperhatikan oleh dosen bahasa Arab dalam pembelarannya

d. Bagaimana tanggapan mahasiswa terhadap pendekatan (metode) yang digunakan tersebut?

\section{Tujuan Penelitian}

Secara umum penelitian ini bertujuan untuk mengetahui pendekatan (metode) yang digunakan dalam pembelajaran bahasa Arab dengan bahan ajar "Mulakhos Al Arobiyah linnasiin", berikut langkah-langkahnya dan alasan pemilihan pendekatan (metode).

\section{Kerangka teori (Bahasa Arab dan pembelajarannya)}

\section{a. Teori Belajar}

Teori belajar dapat dipahami sebagai prinsip umum atau kumpulan prinsip yang saling berhubungan dan merupakan penjelasan atas sejumlah fakta dan penemuan yang berkaitan dengan peristiwa belajar.

Diantara teori-teori belajar itu adalah: 


\section{- Koneksionisme (Connecsionisme)}

Teori ini dikemukakan oleh Edward L. Thorndike (1874-1919) yang berkesimpulan bahwa belajar adalah hubungan antara stimulus dan respon.

Menurut Hilgard \& Bower (1975) jika perubahan hasil belajar sering dilatih maka eksistensi prilaku tersebut semakin kuat (low of use). Sebaliknya jika prilaku tidak sering dilatih atau digunakan maka akan terlupakan atau sekurang-kurangnya akan menurun (law' of disuse).

Demikian pula dengan pengajaran bahasa Arab semakin sering dilatih maka akan semakin berkesan dan tak terlupakan, karena belajar bahasa adalah bagaimana membentuk suatu kebiasaan (takw'in al-aadah)

\section{- Coditioning}

Simple konditioning menekankan bahwa belajar terdiri atas pembangkitan respon dengan stimulus yang pada mulanya bersifat netral atau tidak memadai. Drill, praktik, pengulangan dan kejadian-kejadian sesuai dengan teori ini ${ }^{3}$

Dalam pengajaran bahasa Arab dikenal dengan "bernain peran" dalam bahasa Arabnya "tamsyil mashad" dan yang lebih komplek lag masyrokhiyah, adalah sesuai dengan teori ini.

\section{- Teori belajar dari Whertaimer, Koher dan Koffien}

Yang dikenal dengan "teori gestalt". Bahwa belajar adalah aktivitas yang menuju pada suatu tujuan tertentu. Ciri-cirinya yang khas adalah menghubungkan bagian-bagian dari situasi yang bersangkuatan dengan perbuatan belajar itu untuk mendapatkan suatu pola keseluruhan. ${ }^{4}$

Baik Peaget maupun Gestalt mengajukan akan (1) pengalaman perlu diorganisasikan dan (2) pengalaman-pengalaman masa lampau sangat mempengaruhi pengalaman-pengalaman sekarang. Bagaimana agar pengajaran bahasa Arab bisa memberikan pengalaman-pengalaman yang berarti itulah yang menjadi- tugas-kita.

\section{b. Bahasa Arab dan Prinsip-Prinsip Pengajarannya}

\section{- Bahasa Arab}

Willian Benton dalam bukunya "Encylopedia Britannica" tentang semitic language mengatakan bahwa " bahasa Arab adalah salah satu dari rumpun bahasa smit". 
Lebih lanjut dia membagi bahasa-bahasa smit kepada 1) Smit utara yang terbagi menjadi smit tenggara seperti akadini dan smit barat laut yakni Ibriyah, Finiqiyah dan Aramiyah, 2) Smit selatan terbagi menjadi Arab selatan Habasyah dan Smit timur laut. Dan bahasa Arab merupakan contohnya.

\section{- Prinsip-Prinsip pengajarannya}

Dalam buku "Usus al-Ta'lim al Lughoh al Ajnabiyah" disebutkan bahwa prinsip-prinsip pengajaran bahasa adalah:

(1) Prinsip Apersepsi (al Takhdhir al Mabda'i )

yang dimaksud dengan prinsip ini adalah, bagaimana cara memahami kondisi orang yang belajar bahasa, dan mencakup beberapa hal berikut ini:

- Kemampuan orang dewasa dan anak dalam belajar bahasa adalah berbeda, kemampuan anak akan terus cepat merekan bahasa dibanding dengan orang dewasa, sehingga untuk orang dewasa memerlukan latihan tertentu.

- Belajar bahasa adalah ketrampilan (skill ) bukan ilmu

- Dua cara dalam memperoleh ketrampilan yang baik, 1)dengan cara mempraktekkan tata bahasa, 2) berusaha secara terus menerus dengan menirukan bahasa yang benar dari teman yang lain

- Membetulkan yang salah

- Memasukkan unsur unsur alamiyah dalam proses belajar mengajar

- Penguasaan bahasa secara tidak langsung

(2) Prinsip penyajian awal (Taqdiimul Uluzwiyat)

Ciri-ciri prinsip ini adalah:

- Menyajikan istima' dan kalam (berbicara) terlebih dahulu kemudian baru membaca dan menulis. Prinsip ini dikenal dengan menggunakan metode "syamiyah syafawiyah"

- Pembelajaran kalimat sebelum pembelajaran kata

- Pembelajaran mufrodat/kosa kata seperti ( اكتب , كتب , يكتب)

- Pembelajaran bahasa dengan kecepatan normal

(3) Prinsip ketelitian (al Diqqoh) 
Maksud dari prinsip ini adalah hendaknya pengajar tidak memberikan kesempatan pada pembelajar untuk melakukan kesalahan, hal ini untuk menghidarkannya dari kebiasaan untuk melakukan kekeliruan dalam berbahasa, baik dalam dialek, intonasi, suara, susunan kalimat dan makna

(4). Prinsip Gradasi (al Darjiyyah)

Yang dimaksud dengan prinsip ini adalah:

- Pembelajaran bahasa untuk materi nahwu dan soraf dimulai dari bentuk yang paling mudah menuju yang sulit, dari bentuk ma' lum (aktif) berpindah ke majhul (pasif)

- Pembelajaran bahasa sesuai dengan langkah-langkah yakni dari yang pokok menuju yang lainnya, dari yang penting menuju yang lebih penting, dari yang global menuju pada yang subtansional

- Gradasi dalam memberikan kosa kata, dari mufidah menuju ke wadhifah

(5) Prinsip kerinduan (al Tasywiq)

Langkah-langkah yang membantu pengajar dalam merealisasikan prinsip ini dalam kelas adalah:

- Menjauhkan dari suatu hal yang menjadikan siswa bingung dan gaduh

- Menumbuhkan rasa keberhasilan yang terlah dicapai oleh siswa telah maju selangkah

- Memberikan reinvorcement secara tenus menerus atas jawaban yang benar

- Membangkitkan persaingan sehat antar siswa, jiwa persaingan ini bisa dibentuk melalui perlombaan, permainan, dan lain-lain

- Memasukkan unsur mainan dalam latihan-latihan

- Variasi dalam pembelajaran

- Menjadikan hubungan siswa dan guru sebagai hubungan yang mendidik

(6) Prinsip terus menenus, kekerasan, kekuatan (Sholabah)

Yang dimaksud dengan prinsip ini adalah:

- Pengajaran dilakukan dengan cara metode praktek bukan dengan metode penjelasan kaidah, khususnya bagi pemula

- Penjelasan makna dilakukan dengan jalan memperagakan semaksimal mungkin 
- Memahamkan siswa dengan cara mengulangi contah-contoh yang mungkin dijelaskan dengan jalan termudah dan yang paling banyak memiliki keterkaitan dengan makna dengan bentuk tulisan.

\section{Bahasa Arab dan Metode Pembelajarannya}

Metode pengajaran bahasa merupakan unsur terpenting dalam proses belajar mengajar, sehinga banyak disorot oleh banyak orang. Ada beberapa pendapat mengenai metode pengajaran, diantaranya:

Abdur Rohman Ghunaimah "metode mengajar adalah cara-cara yang praktis dalam mencapai tujuan pengajaran"

Athiyah Al-Abrosyi "metode mengajar adalah jalan yang kita ikuti untuk memberikan pengertian kepada murid tentang segala macan materi dalam bergai pelajaran"

Proyek Pembinacn Perguruan Tinggi Agama" metode mengajar adalah suatu teknik penyampaian bahan pelajaran kepada murid, ia dimaksudkan agar murid dapat menangkap pelajaran dengan mudah efektif dan dapat dicerna oleh mereka dengan baik".

Dari beberapa pendapat diatas, maka metode pengajaran (pembelajaran) dalah suatu cara yang digunakan oleh guru untuk menyampaikan materi pelajaran guna mencapai tujuan tertentu (pembelajaran)

Metode pengajaran (pembelajaran) bahasa banyak sekali diantaranya:

\section{Direct Method (Al Thoriqoh Al Mubasyarah)}

Direct artinya langsung. Direct method yaitu suatu cara menyajikan materi pelajaran bahasa asing dimana guru langsung menggunakan bahasa asing yang dipelajari tersebut sebagai bahasa pengantar dan tampa menggunakan bahasa anak didik sedikitpun dalam mengajar.

Tujuan utama metode ini adalah mengantarkan anak didik dalam wakku singkat untuk berfikir dengan menggunakan bahasa asing yang dipelajarinya tampa membutuhkan penerjemahan ke atau dari bahasa ibu.Metode langsung ini metode yang paling banyak digunakan dalam mengajarkan bahasa asing. Diantara ciri-ciri metode ini adalah :

Ulul Albab, Vol. 3 No. 2, 2001 
- Memberikan prioritas pada kemahiran bercakap atas dasar bahwa bahasa pada dasarnya adalah percakapan

- Menghidari penggunaan bahasa ibu

- Menggunakan tehnik langsung dalam mengajarkan kata atau kalimat

- Pengajaran gramatikal diajarkan secara fungsional

- Menggunakan tehnik menirukan dan menghafal dalam proses belajar mengajar.

Meskipun demikian, metode ini tidak terhindar pula dari kritikan oleh para ahli bahasa dan pendidikan karena memiliki kelemahan- kelemahan antara lain:

- Hanya menekankan pada kemahiran bercakap saja sedang kemahiran lainnya diabaikan

- Membutuhkan banyak tenaga karena tidak menggunakan bahasa ibu sama sekali .

- Perhatian yang kurang terhadap gramatika sehingga menyebabkan minimnya pengetahuan mereka tentang tata bahasa asing yang dipelajari

- Kurang memberikan waktu latihan kepada peserta didik untuk memantapkan pengetahuan dan kemampuannya

- Pengajaran menjadi pasif

Sedang kelebihan ( kebaikan ) metode ini antara lain:

- Anak didik termotivasi untuk dapat menyebutkan dan mengerti kata-kata atau kalimat dalam bahasa asing yang diajarkan

- Peserta didik memperoleh pengalaman langsung dan praktis dalam mempelajari bahasa asing. ${ }^{6}$

\section{Reading Method (Thoriqoh Al Qiro'ah)}

Yaitu menyajikan materi pelajaran dengan cara lebih dahulu mengutamakan membeca sehingga bagi sekolah-sekolah yang bertujuan mengajarkan kemahiran membaca dalam bahasa asing, maka metode ini sangat cocok.

Dan diantara kelebihan metode ini adalah:

- Siswa dapat membaca dan memahami bacaan bahasa asing dengan lancar

- Dapat mrnggunakan intonasi bacaan asing sesuai dengan kaidah membaca yang benar. 
Sedangkan kekurangan dari metode ini adalah:

- Bagi para pemula, akan terasa agak sukar diterapkan, karena mereka masih sangat asing untuk membiasakan lidahnya dalam membaca literatur asing

- Pengajaran bisa jadi bersifat verbalisme. Hal ini dikarenakan anak didik diutamakan untuk dapat melafalkan kata sehingga arti dan makna kata kadangkadang kurang diutamakan. ${ }^{\text {? }}$

\section{Grammar Method (Thoriqotul Al Qowaid)}

Yaitu cara menyajikan materi pelajaran dengan jalan menghafal aturan-aturan atau kaidah tata bahasa asing. Dalam hal ini percakapan tidak dipentingkan. Dan diantara kelebihan metode ini adalah:

- Siswa dapat membaca dan menulis sesuai dengan kaidahnya

- Mempermudah pengajaran bagi guru yang hafal kaidah tersebut meskipun kurang cakap dalam percakapan

Sedangkan kekurangan dari metode ini adalah:

- Metode ini bertentangan dengan hakekat pengajaran bahasa, dimana orang belajar bahasa dimulai dari percakapan bukan dari gramatikalnya

- Jalannya pengajaran bisa membosankan, bila guru kurang mampu memodifikasi metode mengajar

- Mereka menjadi pasif karena penguasaan gramatika tidak dengan sendirinya menguasai percakapan. ${ }^{8}$

\section{Translation Method (Thorigoh Al Tarjamah)}

Yaitu metode dengan cara menterjemahkan, dengan kata lain menyajikan pelajaran dengan menerjemahkan buku-buku bacaan bahasa asing kedalam bahasa ibu, dan buku-buku tersebut tentunya telah direncanakan sebelumnya. Dan diantara kelebihan metode ini adalah:

- Metode ini selain mudah dilaksanakan juga murah. Karena melalui metode ini seorang gura yang mengajar tidak mesti menguasai bahasa asing secara aktif

- Tidak menuntut mereka untuk cakap secara aktif berbahasa asing, namum yang terpenting mampu menerjemahkan bahasa asing secara baik dan benar 
- Dapat meningkatkan pengetahuan yang luas karena dengan menguasai dan mampu menerjemahkan bahasa asing maka tranformasi ilmu pengetahuan mudah diserap dan dikuasai

- Dapat menghasilkan nilai tambah, dimana jika ia mampu atau trampil menerjemahkan buku-buku bacaan literatur asli, maka dapat mendatangkan uang

Sedangkan kekurangan dari metode ini adalah:

Kurang menjamin anak didik mampu bercakap-cakap dengan bahasa asing Metode ini terasa sulit, karena untuk dapat menerjemahkan dengan baik dan benar diperlukan penguasaan gramatika dan pengetahuan serta wawasan yang baik dan luas

- Siswa dituntut untuk rajin membuka kamus, dan rajin membuka buku. ${ }^{9}$

\section{Grammar Traslation Method (Thoriqoh Al Qoawid Wa Al Tarjamah)}

Metode ini merupakan gabungan dari metode gramatika dan tarjamah. Diantara ciri-ciri dari metode ini adalah:

- Menekankan pada kemampuan qiroah, kitabah dan tarjamah namun kurang memberikan perhatian pada kalam

- Menggunakan bahasa ibu sebagai pengantar

- Menekankan segi gramatika dalam memahami teks

- Banyak melakukan analisa gramatika dalam memahami teks

Kelebihan dan kebaikan dari metode ini adalah:

- Tampa disadari siswa memperoleh pengetahuan dari keduanya sehingga pengetahuan tersebut menjadi utuh

- Meskipun secara aktif siswa kurang mampu, namum secara pasif siswa mampu Sedangkan kekurangan dari metode ini adalah:

- Mengabaikan kemahiran kalam, padahal pengertian utama berbahasa adalah bercakap-cakap atau dialog

- Lebih banyak menggunakan bahasa ibu sebagai pengantar. ${ }^{10}$ 


\section{Electic Method (Al Thoriqoh Al Intiqoiyah)}

Yaitu cara menyajikan pelajaran bahasa asing di depan kelas melalui macammacam kombinasi metode, misalnya direct dan grammar method, methode ini memerlukan persiapan yang baik dan kesungguhan dalam mempraktekkan metode ini. $^{11}$

\section{Audio Lingual Method}

Metode ini didasarkan pada anggapan bahwa bahasa dapat dibentuk melalui latihan-latihan. Metode ini memiliki asumsi-asumsi sebagai berikut:

- Bahasa pada adasarnya adalah pecakapan, oleh karena itu dalam pengajaran bahasa asing yang ditekankan adalah aspek kalam(percakapan)

- Dalam mengajarkan bahasa harus mengikuti urutan bahasa sebagai berikut, mendengar (istima'), berbicara( kalam), membaca( qiroah), menulis(kitabah)

- Cara belajar bahasa asing sebenarnaya sama dengan cara bayi memperoleh bahasa

- Guru terbaik dalam pengajaran bahasa adalah pemakai bahasa itu sendiri

Namun demikian, metode ini tak lepas dari kritikan oleh ahli bahasa dan pendidikan, yaitu:

- Kalam bukanlah satu-satunya kemahiran dalan bahasa asing

- Urutan dalam mempelajari bahasa seperti diatas bukanlah urutan yang mesti demikian

- Mempelajari bahasa dengan cara meninukan dan mengulang bisa saja, akan tetapi akan lebih baik kalau disertai dengan penjelasan

- Tidak selalu pemilik bahasa menjadi guru terbaik dalam pengajaran bahasa asing. 12

Agar metode yang hendak dipakai pengajar dalam proses belajar mengajar merupakan metode yang baik, maka pengajar harus memperhatikan faktor-faktor yang dapat mempengaruhinya, antara lain adalah:

1. Tujuan pengajaran, dimana pengajar harus menggunakan metode yang sekiranya mengarah pada tercapainya tujuan pengajaran 
2. Peserta didik, mereka adalah yang akan menerima dan mempelajari materi itu. Untuk itu guru pun harus berusaha untuk menggunakan metode yang sesuai denagan kondisi siswa agar mereka mengerti dan faham terhadap materi yang diajarkan.

3. Materi pelajaran

4. Fasilitas (media), sebelum menentukan dan menggunakan suatu metode guru hanus mengetahu apakah fasilitas yang mendukung penggumaan metode tersebut ada atau tidak

5. Guru, sebelumnya guru harus intropeksi diri, apakah mampu menggunakan metode itu atau tidak

6. Situasi dan kondisi (lingkungan)

\section{d. Maharoh Al Arba' (Istima', Kalam, Qiroah, dan Kitabah) Dan Pembelajarannya}

- Istima'

Istima'(mendengar) merupakan kegiatan yang sangat penting dalam kehidupan kita, dan juga merupakan sarana yang pertama kalinya digunakan oleh seseorang dalam hidup untuk bisa berinteraksi dengan orang lain. Dengan Istima' (mendengar) seseorang memperoleh sebuah kosa kata, gaya bahasa, bentuk bahasa, dan tata bahasa atau skil bahasa yang lain seperti kalam, qiroah, dan kitabah.

Kemampuan seseorang membedakan antara suara huruf merupakan syarat utama dalam maharoh ini, karena ketika seseorang pertama kali belajar bahasa, maka yang ia hadapi adalah bunyi suara bahasa its. Oleh sebab itu ketika kita mengajarkan pada siswa maka harus diucapkan dengan cara yang benar dan tepat, yang memungkinkan siswa bisa denga mudah menguasai kesulitan yang dihadapi.

Secara umum kesulitan yang dihadapi oleh siswa dalam belajar maharoh istima' adalah membedakan suara Mad (suara panjang) seperti dalam kata dan suara Tasdid / Tad'if contoh dalam kata dan al Syam-siyah dan al qomariyah contoh 


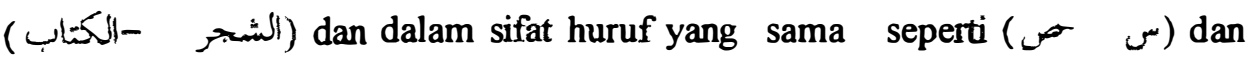
masih banyak yang lain. Maka bentuk-bentuk latihan yang harus diberikan pada siswa antara lain dengan memberikan latihan mengucapkan bunyi suara dengan ucapan yang benar (sesuai dengan tempat bunyi suara itu keluar) disamping itu mengenalkan huruf dan kharokat (الصائة الأصوات الصامتة و )

\section{- Kalam}

Kalam (berbicara) dalam bahasa kedua (asing ) merupakan kemampuan dasar diantara beberapa skil, yang juga merupakan cerminan tujuan dari beberapa tujuan apabila seseorang belajar bahasa asing, disamping itu kalam adalah satusatunya sarana yang sangat penting dalam berinteraksi, kebutuhan ini semakin meningkat ketika kita memasuki era globalisasi yang sudah tidak ada sekat lagi antara negara dan benua.

Latihan seperti penggunaan ungkapan-ungkapan dalam perkenalan (Ta' aruf), ucapan-ucapan selamat (Takhiyah), ucapan-ucapan selamat tinggal/sampai jumpa ( $\mathrm{Al} \mathrm{Wada')} \mathrm{dan} \mathrm{ungkapan-ungkapan} \mathrm{suka} \mathrm{cita} \mathrm{(Tarhib)} \mathrm{atau} \mathrm{sebaliknya.} \mathrm{Dan} \mathrm{bentuk-}$ bentuk latihan yang bisa diberikan pada siswa antara lain memberikan latihan dengan kalimat perintah “Apa yang anda kerjakan"(ماذا تفعل)

\section{- Membaca}

Membaca (qiro'ah) adalah salah dari empat skill yang sangat penting yang harus diperhatikan pula oleh seseorang yang belajar bahasa asing (guru yang mengajarkan bahasa asing maupun siswa yang belajar). kemampuan membaca tidak hanya sebatas membuyikan rumus-rumus yang tertulis dalam bentuk teks akan tapi lebih dari itu, membaca memerlukan juga kemampuan intelektual dan pengalaman siswa yang lain.

Beberapa Kemampuan Yang Harus Dikuasai Siswa dalam Maharoh Qiroah

- Kemampuan membedakan huruf dan mengetahui hubungan antara huruf dan bunyi suara yang dikehendaki

- Kemampuan mengenal kata dalam bentuk jama'dan bentuk mufrot

- Kemampuan dalam memberikan arti kata yang dikehendaki dalam sebuah teks dan konteks atau memahami ma'na dilalah

- Mengerti tentang urutan susunan kata dalam sebuah kalimat 
- Mampu mengetahui dan mengikuti pokok pikiran yang terdapat dalam sebuah teks melalui kata sambung dan beberapa arti yang menunjukkan hubungan tersebut.

- Mampu mengeluarkan pokok pikiran dalam sebuah paragraf.

\section{Macam-Macam Qiroah (membaca)}

Membaca jika dilihat dari sisi sipembaca maka dapat dikelompokkan menjadi dua:

- Membaca(qiroah) Shomitah, iidak bersuara artinya membaca dengan jalan melihat saja pada teks tampa membuyikan suara dan mengerakkan lidah atau mulut.tujuan dari qiroah shomitah ini adalah untuk memeari dengan jalan cepat kesuiitan kesulitan yang terdapat pada teks bacaan seperti: arti kata dan susunan kalimat dan ma'na ad dilaly

- Membaca (qiroah) Jahriyah, berswara, artinya dengan jalan membuyikan rimus-ruraus yang ada pada teks, dengan tujuan untuk memperoleh kebiasaan membaca dengan baik sesuai dengan intonasi dan tempat keluamya huruf, disamping pemahaman dari teks itu sendiri.

Jika dilihat dari konsep pembelajaran bahasa maka qiro'ah dibedakan menjadi

- Qiroah Mukassafah, artinya qiro'ah yang digunakan sebagai sarana untuk belajar kosa kata (mufrodat), tata bahasa (taraakib) yang baru. Adapun tahapan tahapan yang harus dilakukan dalam qiroah ini adalah: membaca bunyi suara huruf sebuah kata dengan baik dan benar, kemudian membaca untuk memahai apa yang telah diucapakn, dan yang terakhir adalah membaca untuk memperlancar bacaan dengan baik dan benar.

- Qiro'ah Muwassa'ah, artinya qiro'ah yang melengkapi fungsi qiro'ah makassafah, dan biasanya qiro'ah ini memakai bentuk cerita pendek maupun panjang dengan tujuan untuk memperkaya mufrodat dan tata bahasa maupun ungkapan-ungkapan bagi siswa.

Sedangkan menurut isi bahan bacaan, qiro'ah dibedakan menjadi tiga:

- Qiro'ah qishosiyah,yaitu qira'ah yang isi bacaannya adalah dalam bentuk cerita baik cerita pendek atau panajang atau cerita bergambar, seperti ceritacerita para rosul dan nabi, para sahabat, tokoh tokoh Islam dan lain sebagainya. 
- Qiro'ah wasfiyah, yaitu qiro'ah yang bahan bacaannya bersifat diskriftif tentang sesuatu hal, seperti tema ar rihlah, yaumul id, al haji dll.

- Qiro'ah ilmiyah, artinya qiroah yang bahan bacaannya besifat ilmiyah (sistematis) seperti kitab-kitab keagamaan, umum dan lain-lain.

\section{- Menulis}

Menulis (Kitaabah) adalah salah dari empat skill yang tidak mudah untuk dipelajari, ia bukan skil yang sederhana akan tetapi memadukan dari tiga kemampuan sebelumnya (Istima', Kalam, Qiro 'ah), seseorang yang belajar menulis ia harus memusatkan kemampuannya untuk menulis huruf-huruf dan kata-kata dengan baik dan benar sesuai dengan apa yang telah disepakati oleh pemilik bahasa baik dari segi bentuk hurufnya maupun katanya. Menulis (kitabah) merupakan seluruh aktivitas yang dimulai dengan merubah suara yang didengarnya menjadi huruf, kata, kalimat yang sesuai dengan kesepakatan pemilik bahasa.

\section{Macam-Macam Kitabah}

Apabila menulis (kitabah) dimulai dengan cara menulis sebuah huruf dan berakhir dengan menulis sebuah makalah (karya ilmiyah), cerita (pendek atau panjang), sesungguhnya belajar menulis harus dimulai jauh sebelum itu, yaitu mengenali bunyi huruf dan bentuk hurufnya, perbedaan bunyi huruf yang mempuyai tempat keluar (Makhroj) yang berdekatan (Sunaiyah Shugro). Para ahli pengajaran bahasa membagi kemapuan menulis menjadi beberapa tahapan :

pertama, tahapan sebelum menulis yang meliputi:

- mendengarkan bunyi huruf dan bunyi kata bahasa yang hendak ditulis)

- Tahapan melatih gerakan otot-otot tangan untuk menulis ( yaitu menulis bunyi huruf, sesuai dengan kemampuannya yang bersifat sepenggal-penggal) $K e d u a$, tahap menulis yang sebenarnya yang meliputi prinsip-prinsip penulisan apa yang didengar, diketahui dari bahasa itu.yang meliputi:

- Mengetahui terlebih dahulu huruf dan menyambung pengalan-pengalan kata.

- Menyalin huruf, penggalan kata, kata, kaimat, dan teks dalam bentuk tulisan.

- Imla' dengan jenis- jenisnya.

- Ta’bir dengan jenis- jenisnya (Al muwajjah, Al musawar, Al khur). 
Ada beberapa tahapan imla' yang harus ditempuh di antaranya:

- Al Imla' Al Hijaiy, yaitu mengajarkan imla' pada siswa dengan cara menyuruh siswa untuk menulis beberapa mufrodat, baik di bukunya atau pada papan tulis, atau dengan cara guru menulis pada papan tulis kemudia guru menghapusnya dan siswa disuruh menulis tulisan yang telah dihapus

- Al Imla' Al manqul, yaitu siswa menyalin tulisan yang ada di buku atau papan tulis Dalam imla' ini hendaknya diperhatikan hal-hal sebagai berikut: hendaknya teks itu sedikit atau pendek, dan teks itu telah dibaca oleh siswa, hendaknya imla' ini bertujuan agar siswa tidak salah dalam menulis.

- Al Imla' Al Mandzur, yaitu imla' dengan cara dibacakan oleh guru, dan siswa mendengarkan dan memahmi teks tersebut kemudian baru menulisnya. Sebaiknya teks yang digunakan teks yang dipakai dalam qiroah atau mukhadatsah, dan hendaknya diperhatikan hal-hal sebagai berikut: hendaknya guru membaca beberapa kata sekaligus bukan kata-perkata, hendaknya guru membacakannya dengan cara lazimnya membaca, dan hendaknya juga meng-imla' tanda baca juga (alamatut tarqim)

- Al Imla' Al Istimaiy, yaitu siswa mendengarkan teks beberapa kali, memahami artinya dan mengucapkannya beberapa kalimat yang mempuyai kemiripan dan yang sulit, baru setelah itu siswa disuruh untuk menulis.

\section{Metodologi penelitian}

Beberapa hal yang perlu dijelaskan berkenaan dengan metodologi penelitian ini adalah :

\section{a. Metode Penelitian}

Penelitian ini menggunakan metode diskriftif yaitu bertujuan melukisksn variabel atau kondisi "apa yang ada" di lapangan. Dengan menggunakan metode ini akan diperoleh gambaran yang obyektif tentang "pendekatan (metode) yang digunakan dalam pembelajaran bahasa Arab dengan bahan ajar "Mulakhos $A l$ Arobiyah linnasiin".

b. Populasi dan Sampel 
Populasi

Populasi merupakan daerah atau lokasi penelitian yang akan diteliti. ${ }^{13}$ Dalam hal ini yang akan dijadikan obyek penelitian adalah Program Khusus Perkuliaan Bahasa Arab (PKPBA)Universitas Islam Indonesia Sudan dh. STANN Malang yang meliputi: Dosen yang jumlahnya (82) dan Mahasiswa (1118) angkatan 2002/ 2003

\section{Sampel}

Sampel adalah bagian dari populasi yang akan menjadi sumber data penelitian. Dalam hal peneliti hanya mengambil 75 dosen sebagai sampel, dan mahasiswa: dari populasi yang ada peneliti mengambil 200 mahasiswa sebagai sampel, karena penelitian deskriptif ini memiliki populasi yang besar sehingga diambil 10 sampai 20 persen dari populasi yang dapat dijangkau ${ }^{14}$

\section{Teknik Pengumpulan Data}

Untuk mendapatkan data dari penelitian tentang "Pendekatan (Metode) yang digunakan dalam pembelajaran bahasa Arab dengan bahan ajar"Mulakhos $A l$ Arobiyah linnasiin". Program Khusus Perkuliahan Bahasa Arab" Sekolah Tinggi Agama Islam Malang, peneliti menggunakan beberapa instrumen pengumpul data ,yakni:

\section{Angket}

Angket adalah alat untuk mendapatkan keterangan, data-data, realita-realita lapangan yang berhubungan dengan kenyataan tertentu. Peneliti menggunakan instrumen ini untuk mendapatkan data utama dari dosen sampel dan mahasiswa sampel.

\section{Wawancara}

Wawancara adalah suatu kegiatan yang dilakukan untuk mendapatkan informasi secara langsung dengan mengungkapkan pertanyaan-pertanyaan pada para responden. Peneliti menggunakan wawancara untuk mendapatkan data pendukung dari pengelola PKPBA dan beberapa wali kelas.

3. Observasi 
Observasi yaitu teknik pengumpulan data dimana penyelidik mengadakan pengamatan langsung (tanpa alat terhadap gejala-gejala yang dihadapi/diselidiki) baik pengamatan itu dilaksanakan/dalam situasi buatan yang harus dilakukan

4. Teknik Analisa data

Data yang diperoleh oleh peneliti dalam hal ini adalah data kualitatif yang didapat dari observasi , angket, wawancara dan studi dokumen. Pendekatan kualitatif dimaksudkan untuk mendapatkan keterangan yang mendalam dari obyek yang bersangkutan. Pendekatan kualitatif menunjuk kepada prosedur-prosedur riset yang menghasilkan data kualitatif yang berupa ungkapan-ungkapan atau catatancatatan itu sendiri atau tingkah laku yang terobservasi.

Dari data kualitatif ini diolah dengan pendekatan kuantitatif yakni dengan perhitungan "distribusi Prosentase"15

\section{Hasil penelitian}

Dari data yang diperoleh dalam penelitian akan disajikan dalam bentuk tabeln dan merupakan jawaban dari rurnusan masalah yang diajukan dalam penelitian ini. Adapun data itu sebagiamana berikut ini :

Tentang model pendekatan(metode) pembelajaran Bahasa Arab yang digunakan

\begin{tabular}{|l|c|c|c|c|}
\hline \multicolumn{1}{|c|}{ Altematif jawaban } & N & F & $\%$ & Ket \\
\hline Direct Method & & 42 & 56 & \\
Grammar ang Tranlation Method & & 3 & 4 & \\
Aural Oural Method & & 6 & 8 & \\
Reading Method & 75 & 9 & 12 & \\
Eclectic Method & & 15 & 20 & \\
$\ldots \ldots . . . . . . . . .$. & & & & \\
\hline \multicolumn{1}{|c|}{ Jumlah } & & 75 & 100 & \\
\hline
\end{tabular}


Tabel tersebut di atas menerangkan bahwa dalam pembelajaran bahasa Arab di PKPBA para dosen kebanyakan menggunakan pendekatan (metode) "Direct Method" atau "Thoriqoh al Mubasyaroh",dan sebagian diantara mereka menggunakan "Eclectic Method" atau "al Thoriqoh al Intiqoiyoh". Sedangkan alasan penggunaan pendekatan (metode) adalah sebagai berikut.

\begin{tabular}{|l|c|c|c|c|}
\hline \multicolumn{1}{|c|}{ Alternatif Jawaban } & $\mathrm{N}$ & $\mathrm{F}$ & $\%$ & Ket \\
\hline A.Tahu langkah-langkahnya & & 18 & 24 & \\
B.Sesuai dengan kondisi kelas & 75 & 45 & 60 & \\
C....................... & & 12 & 16 & \\
\hline Jumlah & & 75 & 100 & \\
\hline
\end{tabular}

Dari tabel di atas menerangkan bahwa alasan penggunaan atau pemilihan pendekatan (metode) dalam pembelajaran bahasa Arab di PKPBA adalah karena, pendekatan (metode) tersebut sesuai dengan kondisi kelas (siswa), kemudian alasan kedua karena tahu langkah-langkahnya. . Kemudian faktor-foktor yang sering diperhatikan dalam pembelajaran Bahasa Arab

\begin{tabular}{|l|c|c|c|c|}
\hline \multicolumn{1}{|c|}{ Alternatif jawaban } & N & F & $\%$ & Ket \\
\hline A.Materi & & 15 & 20 & \\
B.Pendekatan (metode) & & 40 & 53,3 & \\
C.Media (Sarana Prasarana) & & 5 & 6,7 & \\
D.Lingkungan (Bi'ah) & 75 & 6 & 8 & \\
E.Siswa & & 6 & 8 & \\
F.............. & & 3 & 4 & \\
& & & & \\
\hline \multicolumn{1}{|c|}{ Jumlah } & & 75 & 100 & \\
\hline
\end{tabular}


Tabel di atas menerangkan bahwa foktor utama yang selalu diperhatikan dalam pembelajaran bahasa Arab adalah"Pendekatan (Metode)", baru kemudian materi, bi'ah (lingkungan), siswa, dan sarana prasarana (modia).

Adapun pendapat mahasiswa, tentang cara mengajar yang digunakan selama ini adalah sebagai berikut

\begin{tabular}{|c|c|c|c|c|}
\hline Alternatif Jawaban & $\mathrm{N}$ & $\mathrm{F}$ & $\%$ & Ket \\
\hline A.Suka & & 78 & 39 & \\
\hline B.Tidak Suka & 200 & 18 & 9 & \\
\hline C. Kadang-Kadang & & 104 & 52 & \\
\hline Jumlah & & 200 & 100 & \\
\hline
\end{tabular}

Tabel tersebut menerangkan bahwa dengan cara mengajar yang digunakan oleh dosen, kadang-kadang mahasiswa suka dan kadang-kadang tidak, dikarenakan antara satu dosen dengan dosen yang lain berbeda cara mengajarnya, ada yang sabar menuntun, mudah dipaharni, monoton tidak ada candanya, selalu di kelas dan selalu menggunakan bahasa Arab. Sedangkan mengenai proses belajar mengajar bahasa Arab di PKPBA sebagaimana berikut ini

\begin{tabular}{|l|c|c|c|c|}
\hline Alternatif Jawaban & N & F & $\%$ & Ket \\
\hline Menyenangkan & \multirow{2}{*}{200} & 20 & 10 & \\
Membosankan & & 143 & 16,5 & \\
Biasa-biasa saja & & 73,5 & \\
\hline Jumlah & & 200 & 100 & \\
\hline
\end{tabular}

Tabel tersebut diatas menerangkan bahwa tanggapan mahasiswa tehadap proses pembelajaran bahasa Arab di PKPBA biasa-biasa saja tidak ada yang istimewa karena pendekatan/metodenya monoton, dan sebagian kecil berpendapat membosankan karena materinya sulit, waktunya tidak tepat dan terlalu lama, sedangkan yang berpendapat menyenangkan karena tugasnya sedikit. 


\section{Kesimpulan}

Dari pemaparan teori dan data yang diperoleh dalam penelitian ini maka peneliti dapat menyimpulkan bebrapa hal sebagaimana berikut ini:

1. Bahwa pendekatan/metode yang digunakan dalam pembelajaran bahasa arab dengan materi al Mulakhos al Arobiyah linnasyi' in adalah metode langsung (al Thoriqoh al Mubasyaroh) dan Electic method (al Thoriqoh al Intiqoiyah).

2. Alasan penggunaan pendekatan/metode tersebut diatas, karena pendekatan' metode tersebut sesuai dengan kondisi kelas (mahasiswa)

3. Dalam pembelajaran bahasa Arab foktor yang paling banyak diperhatikan oleh dosen adalah pendekatan/metode, baru kemudian lingkungan (Bi' ah)

4. Tanggapan mahasiswa terhadap pendekatan/metode yang digunakan tersebut biasa-biasa saja, kadang-kadang senang atau sebaliknya.

\section{Saran}

PKPBA (Progran Khusus Perkuliahan Bahasa Arab) hendaknya selalu meningkatkan mutu pembelajaran bahasa Arab, dengan cara memberikan bekal yang cukup (dalam bentuk Pelatihan) akan pendekatan/metode karena banyak diantara para pengajar yang masih kurang pengetahuaanya tentang macam-macam pendekatan/metode berikut langkah-langkahnya, sehingga pembelajarannya tidak terkesan monoton.

\section{Endnotes}

1 Gorys Kerap, Tata Bahasa Indonesia. Ende Flores :Nusa Indah ,1980, hlm. 16

2 Hidayat. Dr. Muhtashor Thuruqt Tadris Lughoh Al Arobiyah lithullabil 5 Almadaris Ma'ahid Indo.Tt, hlm. 24

3 Hamalik Qomar, Dr, Psikologi Belajar Mengajar, Sinar Baru, Argensido Bandung, 1992. hlm. 49

4 Mulyadi, Drs, Pengantar Psikologi Belajar, Biro Ilmiyah, FT. IAIN Sunan Ampel, Malang, 1984.

Vlul Albab, Vol. 3 No. 2, 2001 
5 Zuhairini At.all. Metodologi Pengajaran Pendidikan Agama., Solo Ramadhoni. 1993, hlm. 67

- Tayar Yusuf \& Syaiful Anwar. Metodologi Pengajaran Agama dan Bahasa Arab. Jakarta P.T Raja Grafindo Persada 1997. hlm. 154-155

$7 \quad$ Ibid, hlm. 162-163

$8 \quad$ Ibid, hlm. 168-170

$9 \quad$ Ibid

10 Abdul Haris Rifa'i. 1997, Profesionalisme Pengajaran Eahasa Arab, Makalah, hlm. 6-7

1 Tayar Yusuf \& Saiful Anwar, Opcit, hlm. 184

12 Abdul Haris Rifa'i.,Opcit, hlm. 8-9

13 Suharsimi Arikunto, Prosedur Penelitian, Jakarta Bina Aksara, 1987, hlm. 115

14 Arif Furchan, Pengantar penelitian dalam pendidikan. Usaha Nasional Sby. 1982 hlm. 198

15 Anto Dajan, Pengantar Metode Statisatik, jilid I, LP3ES, 1989, hlm. 103 


\section{Bibliography}

Abdul Harist Rifa'i. Profesionalisme Pengajaran Bahasa Arab-Makalah-

Ali Ahmad Madzkur.DR.Tadris Funun Al Lughoh Al Arobiyah.Maktabah AlFalakh 1984

Anto Sajan, Pengantar Metode Statisatik, jilid 1, LP3ES, 1989

Arif Furchan, Pengantar penelitian dalam pemdidikan. Usaha Nasional Sby. 1982

Gorys Keraf, Tata Bahasa Indonesia. Ende Flores :Nusa Indah ,1980

Hamalik Qomar, Dr, Psikologi Belajar Mengajar, Sinar Baru, Argensido Bandung, 1992.

Harulod Palmar. Principles of Language Study diterjemahkan dalam dalam Bahasa Arab Oleh DR.Soleh Muhammad Nasir, Usus Ta'limul Lughoh Al Ajnabiyah. Tt

Hidayat. Dr. Muhtashor Thuruqt Tadris Lughoh Al Arobiyah lithullabil 5 almadaris ma'ahid Indo.Tt

Kridalaksana, Harmuti, Kamus Sinonim Bahasa Indonesiua, Nusa Indah, Ende, Flores, 1993

Mahmud Kamil An Naqah.DR. Ta'liimul Lughoh Al Arobiyah Linnatiqiina Bilughotin Ukhro, 1985.

Mulyadi, Drs, Pengantar Psikologi Belajar, Biro Ilmiyah, FT. IAIN Sunan Ampel, Malang, 1984.

Parera Jos Daniel, Linguistik Edukasional: Pendekatan,Konsep, dan Teori pengajaran Bahasa. Jakarta,Penerbit Erlangga, 1987.

Pedoman pelaksanaan Perkuliahan Bahasa arab, program khusus Perkuliahan Bahasa Arab STAIN Malang (Tem Peyusun) 2000

Rusdi Ahmad Thoimah Dr. Ta'limul Arobiyah lighoiri Nathiqina biha Manahijuhu Waasalibuhu. Riyad 1987.

Sadtono,E.Metode Belajar mengajar Bahasa Inggris untuk Kemampuan Komunikatif Lisan, Makalah

Soeparma, Drs, Media Pengajaran bahasa, Intan Pariwara Jakarta, 1988

Suharsimi Arikunto, Prosedur Penelitian, Jakarta Bina Aksara, 1987

Ulul Albab, Vol. 3 No. 2, 2001 
104 A. Wahab Rosyadi

Tayar Yusuf \& Syaiful Anwar.Metodologi Pengajaran Agama dan Bahasa Arab. Jakarta P.T Raja Grafindo Persada 1997.

Team Penyusun, Pedoman Pengajaran Bahasa Arab Untuk Perguruan Tinggi' LAIN. Jakarta.Proyek Pengembangan. 1974

Zuhairini At.all.Metodologi Pengajaran Pendidikan Agama, Solo Ramadhoni.1993 